\title{
BEHAVIOR OF THE EMERGENCE OF NATIVE FOREST SEEDLINGS FOR THE PURPOSE OF RECOVERY OF THE RIPARIAN FOREST
}

\author{
Janisson Batista de Jesus ${ }^{1 *}$, Robério Anastácio Ferreira², Dráuzio Correia Gama ${ }^{3}$ \\ ${ }^{1}$ Federal University of Rio Grande do Sul, Porto Alegre, Rio Grande do Sul, Brasil - janisson.eng@gmail.com; ${ }^{2}$ \\ Federal University of Sergipe, São Cristóvão, Sergipe, Brasil - roberioaf@ yahoo.com.br; ${ }^{3}$ State University of Southest of \\ Bahia, Vitória da Conquista, Bahia, Brasil - drauziogama@hotmail.com \\ Received for publication: 06/11/2017 - Accepted for publication: 04/06/2018
}

\begin{abstract}
Understanding the behavior of the emergence of native forest seeds is essential to achieve greater successes in forest recovery. Therefore, this study aimed to evaluate the emergence of native forest species (Cassia grandis L.F., Cecropia pachystachya Trec., Enterolobium contortisiliquum (Vell.) Morong, Guazuma ulmifolia Lam., and Libidibia ferrea var. leiostachya (Benth.) L.P.Queiroz.) in riparian areas of the Piauitinga River, in the municipality of Lagarto (state of Sergipe, Brazil). The experiment was carried out in a randomized block design (DBC) with four blocks in triple scheme $(4 \times 2 \times 6)$ : four forest species emerged (Cassia grandis, Enterolobium contortisiliquum, Guazuma ulmifolia, Libidibia ferrea var. leiostachya), with and without treatment to overcome dormancy, evaluated every fortnight for 90 days (6 periods). It was verified by the statistical analysis that the four species that had emergencies interacted in the two treatments used throughout the six evaluation periods. The species, in both treatments, presented a large number of seeds emerged in the first weeks after sowing, reducing over time. The species studied have a characteristic pattern of emergence over time, considering both seeds with and without treatment to overcome dormancy.
\end{abstract}

Keywords: Environmental degradation, seed dormancy, seed forests.

\section{Resumo}

Comportamento da emergência de plântulas florestais nativas para fins de recuperação da mata ciliar. A compreensão do comportamento da emergência de sementes florestais nativas é essencial para obtenção de maiores sucessos nos trabalhos de recuperação florestal. Sendo assim, este trabalho foi realizado com o objetivo de se avaliar a emergência de plântulas de espécies florestais nativas (Cassia grandis L.F., Cecropia pachystachya Trec., Enterolobium contortisiliquum (Vell.) Morong, Guazuma ulmifolia Lam., e Libidibia ferrea var. leiostachya (Benth.) L.P.Queiroz) em áreas de mata ciliar no Rio Piauitinga, no município de Lagarto (SE). O experimento foi implantado em Delineamento em Blocos Casualizados (DBC) com quatro blocos em esquema triplo (4 × $2 \times 6$ ): quatro espécies florestais emergidas (Cassia grandis, Enterolobium contortisiliquum, Guazuma ulmifolia, Libidibia ferrea var. leiostachya), com e sem tratamento para superação de dormência, avaliadas quinzenalmente durante 90 dias (6 períodos). Verificou-se, pela análise estatística, que houve interação das quatro espécies que tiveram emergência nos dois tratamentos utilizados ao longo dos seis períodos de avaliação. As espécies, em ambos os tratamentos, apresentaram grande parte das sementes emergidas nas primeiras semanas após a semeadura, reduzindo ao passar do tempo. As espécies estudadas possuem um padrão característico de emergência ao longo do tempo, considerando tanto as sementes com e sem tratamento para a superação da dormência.

Palavras-chave: Degradação ambiental, dormência, sementes florestais.

\section{INTRODUCTION}

Preservation of still existing natural ecosystems and the recovery of degraded areas, especially the Permanent Preservation Areas (APP) of riparian areas, are important alternatives to the maintenance and recovery of biodiversity (FERREIRA et al., 2013). In addition, riparian areas have legal significance, because they should be preserved, and those already degraded or in process of degradation by anthropogenic activities must be recovered, since such areas are defined as permanent preservation by brazilian environmental legislation (COSTA et al., 2010). Despite this, studies that assess and monitor the recovery of these ecosystems are unusual (ROCHA et al., 2015).

FLORESTA, Curitiba, PR, v. 49, n. 1, p. 057-068, jan/mar. 2019

Jesus. J.B. et.al.

Electronic ISSN 1982-4688

DOI: $10.5380 /$ rf.v49i1.56202 
One of the rising techniques to environmental recovery has been direct seeding with use of forest species, which appeared as an alternative to speeding up the processes of ecological succession and it has been shown effective for this purpose (PEREIRA et al.,2014). However, the seeds of some forest species present difficulties to emerge in the field because some cause dormancy, which becomes an impeding factor to the propagation of the species. The information about the usage effects of these procedures in the success of the emergence and survival of seedlings, especially under field conditions, are still scarce, even for species of which there are already studies reporting the use of pre-germination treatments to overcome such impediment in restoration activities through direct seeding (PEREIRA et al., 2013).

Knowing the behavior of the species used in forest recovery programs in different abiotic conditions also determines the success of these activities. Thus, understanding the different responses allows a proper reintroduction, in order to ensure a greater emergence capacity, survival and establishment in the field (LIMA et al., 2014). In this study, the hypothesis adopted was that the percentage of emergence of different species analyzed can be influenced by the type of treatment (with and without breaking of dormancy) in interaction with time after sowing. Therefore, this study was conducted in order to evaluate the emergence of seedlings of direct seeding, with and without treatment for overcoming of dormancy, using native forest species and aiming at their use for forest recovery in riparian areas of the river Piauitinga, in the municipality of Lagarto (SE).

\section{MATERIAL AND METHODS}

\section{Characterization of the study area}

The study was conducted in two stretches of riparian forest areas of the Piauitinga river Sub-basin, which belongs to Piauí river drainage basin, in the municipality of Lagarto, in the Center-South region of the State of Sergipe, located between the coordinates $10^{\circ} 34^{\prime}{ }^{\prime} 10^{\prime \prime}$ and $10^{\circ} 45^{\prime} 12^{\prime \prime} \mathrm{S}$ and $37^{\circ} 22^{\prime} \quad 20^{\prime \prime}$ and $37^{\circ} 34^{\prime} 22^{\prime \prime}$ W. The climate of the region is As type, according to Köppen classification, with average precipitation of 1,020.6 mm per year, monthly average maximim temperature between 26 and $32{ }^{\circ} \mathrm{C}$ and minimum between 18 and $22{ }^{\circ} \mathrm{C}$, being the months of July and August the coldest (around $22.5^{\circ} \mathrm{C}$ ) and January the hottest (averaging $26.2^{\circ} \mathrm{C}$ ) (SOUSA et al., 2010). The soils of the region are classified as Red Yellow Argisol, Dystrophic Red Yellow Latosol and Fluvic Neosol (SERGIPE, 2011).

\section{Used species}

The species choice was based on the obtained results in floristic surveys performed in areas of riparian forest located in the four municipalities of Sergipe state, which compose the Piauitinga River drainage basin (Lagarto, Salgado, Boquim and Estância). The availability of seeds in the Cold Chamber of the Department of Forestry Sciences (DCF) of the Federal University of Sergipe (UFS) was considered, as well as their potentialities in relation to the ecological and silvicultural characteristics observed in the works of recovery of degraded areas. The selected species were: the pioneers Cecropia pachystachya Trécul and Guazuma ulmifolia Lam., and the lightdemander climax Cassia grandis L.f.Enterolobium contortisiliquum (Vell.) and Libidibia ferrea var.leiostachya (Benth.) L.P.Queiroz, according to the ecological group classification indicated by Oliveira-Filho et al. (1995).

The fruits of each species were collected in 2011 (with the exception of the fruits of Cecropia pachystachya, which were harvested in 2008) from mother trees in the four municipalities that are part of the Sub-basin of the river Piauitinga. They were carried in polyethylene braided bags and deposited in the UFS' Forest Nursery for subsequent drying and processing. After extraction, the seeds were placed in transparent impermeable plastic bags, weighted, labeled and stored in a cold Chamber, with temperature between 6 and $9^{\circ} \mathrm{C}$ and 60 to $65 \%$ relative humidity, at DCF, where they remained until their use for the study.

\section{Overcoming dormancy treatments}

For overcoming dormancy of used species seeds, pre-germination treatments were used according to studies performed and indicated by the literature. This way, the species Cassia grandis and Guazuma ulmifolia were subjected to chemical scarification through concentrated sulphuric acid, with 30 and 50 minutes in immersion respectively. The same treatment was applied in Libidibia ferrea var.leiostachya and Enterolobium contortisiliquum, both immersed for 50 minutes. Cecropia pachystachya was soaked in destilled water for one hour. After the immersion, the seeds were washed with distilled water for approximately ten minutes to acid removal. The entire process was conducted in the DCF' Forest Seeds Laboratory. 


\section{Experiment implementation}

The field experiment was implemented on July 2nd 2014, in a stretch in both right and left margins of the watercourse of the river Piauitinga, in Brasilia village, in the municipality of Lagarto. Predominant forms of soil use and occupation prior to the study were pasture and agriculture. In this area, manual cleaning was performed through hoeing, removing invasive plants. In order to avoid domestic animals entrance (cattle and horses) present in the surroundings of the experimental areas, the planting selected areas were isolated by barbed wire fences.

Seeding occurred through the selection of two different riparian area stretches at a distance of approximately $300 \mathrm{~m}$, one in each river margin, containing two blocks at a $3 \mathrm{~m}$ distance between them. In each experimental block were distributed ten rows, each composed by ten holes $(30 \times 30 \times 30 \mathrm{~cm})$ in $2.0 \times 1.0 \mathrm{~m}$ spacing between them, with the distribution of the factorial scheme made by random drawing for each row. In this way, each block had 100 holes, totaling 400 holes throughout the study area.

The density of field sowing was based on the viability of the seeds tested in the laboratory for each species, according to the rules for seed Analysis by the Ministry of Agriculture (BRAZIL, 2009). 20 seeds were used per hole for Libidibia ferrea var.leiostachya, which showed $29 \%$ of radicle protrusion in a controlled environment, while Cassia grandis, Enterolobium contortisiliquum, Cecropia pachystachya and Guazuma ulmifolia showed 97\%, 90\%, 46.75\% and 38\% respectively, using 10 seeds in each hole. The seeds of Cassia grandis, Enterolobium contortisiliquum and Libidibia ferrea var.leiostachya were sown at $1.5 \mathrm{~cm}$ deep and Cecropia pachystachya e Guazuma ulmifolia at $1.0 \mathrm{~cm}$, depending on the size of the seeds.

Initial fertilization was conducted with $200 \mathrm{~g}$ of simple superphosphate at 30 days after sowing, when rainfall decreased. The fertilization of coverage was made after the 60 days from sowing, using $150 \mathrm{~g}$ of NPK 20:10:20, through its incorporation into soil by two small holes opening at a distance of $15 \mathrm{~cm}$ from the plants' stem. In order to increase early development of species and reduce competition for light, water and nutrients, each grave was crowning, with minimum radius of $50 \mathrm{~cm}$ in the planted area. In addition, leaf-cutting ants control was performed using bait granules formicide, when the need was verified by the presence of nests in the area.

\section{Soil elevation profile, pluviometric regime, moisture and soil temperature}

In each block, the terrain elevation characterization for the purpose of observing the variation of quota regarding the length and width of the polygon. For this, it was used the optical level N2 model, tripod, pickets and level staff. The data were processed in the program ArcGIS 10.1 in order to generate the terrain elevation model of the study areas. Daily precipitation data were obtained from the meteorological station in the municipality of Boquim (SE), about $28 \mathrm{~km}$ from the study area (nearest data collection point), to verify the influence of precipitation on temperature and soil moisture variables, which can also interfere in species emergence response. For this, both variables were evaluated by field measurements at three points (base, middle and top) along the longitudinal profile of each block, at the depth of $5 \mathrm{~cm}$, with the aid of a geothermometer (Gulterm 180). Weekly soil samples were collected of 0 to $10 \mathrm{~cm}$ layer during the first 90 days after sowing, which were weighted and dried in a heating chamber at $105^{\circ} \mathrm{C}$ for moisture determination (EMBRAPA, 1997).

\section{Field evaluation and emergence data statistical analysis}

Seedling emergence assessments were performed at fortnightly intervals after direct seeding, during the first three months. Seedlings that showed visible protophilo were considered as emerged, the results were expressed in percentage and calculated according to the total number of seeds per species. The species Cecropia pachystachya was excluded because there was no emergence.

Analysis of variance was performed through the F-test to evaluate the triple interaction between factors: four species showed seedling emergence in the field (Cassia grandis, Enterolobium contortisiliquum, Guazuma ulmifolia and Libidibia ferrea var.leiostachya), two treatments (with and without dormency) and six periods of field evaluation (fortnightly), over the 90 days ( 4 x $2 \times 6$ ). The Kolmogorov-Smirnov test was used to check the normality of the errors. Germination data (expressed in percent) were transformed to arcsine square root ratio, and averages of treatments and species were analyzed by Tukey test at 5\%. The comparison of evaluation times was conducted by regression analysis, through SISVAR ${ }^{\circledR}$ software (FERREIRA, 2011).

FLORESTA, Curitiba, PR, v. 49, n. 1, p. 057-068, jan/mar. 2019

Jesus. J.B. et.al.

Electronic ISSN 1982-4688

DOI: $10.5380 /$ rf.v49i1.56202 


\section{RESULTS}

\section{Soil elevation profile, pluviometric regime, moisture and soil temperature}

The topography of the terrain was differentiated in each analyzed block. The blocks 1 and 2 showed more sloping relief with flatter base (Figure 1). As it moved away from the river margin, the quota value increased significantly. In block 1, there is a larger difference in height from the top to the bottom of the terrain $(1.34 \mathrm{~m})$. The block 2 follows the same typographic context, but with slope on the central portion of the area. The block 3 presents the top higher than the base, but with no quota values and a sharp cut in one side at the top, while the middle section has a larger quota in central area, with relegation at both ends. The block 4 presented a fully uneven topography and, different from the others, with the top showing lower quotas than the base, and therefore there is an uphill, and with the highest region in one of the ends of the middle portion of the area.

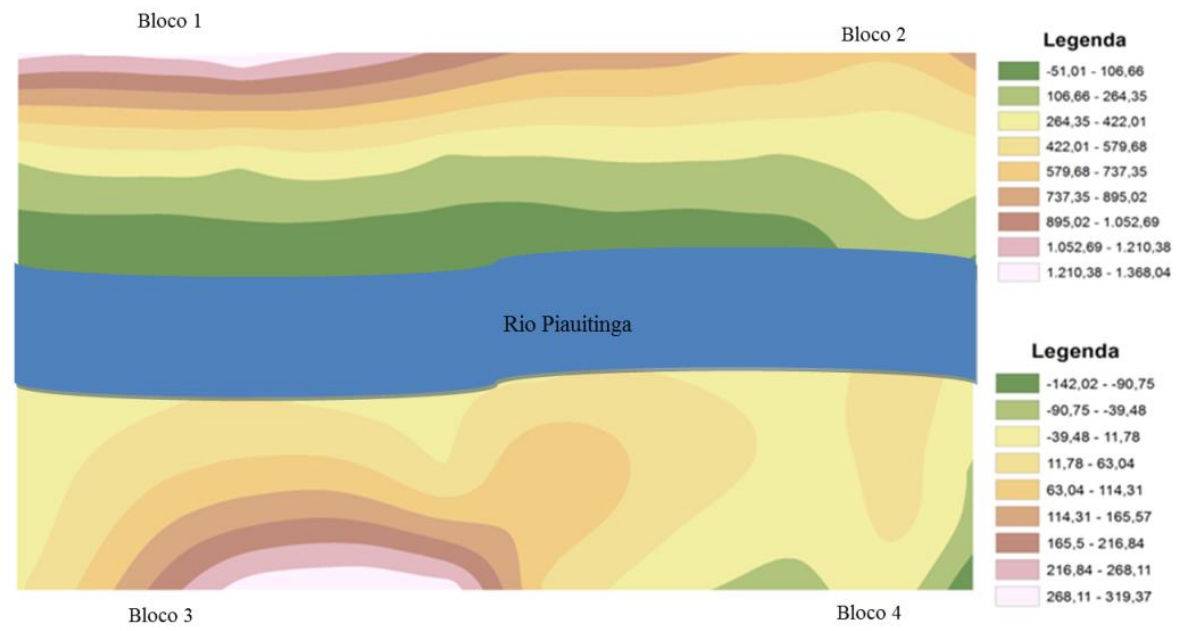

Figure 1. Digital land modeling $(\mathrm{mm})$ characterizing quota differences between the top, base and the middle portion of the terrain in relation to the watercourse, in the experimental areas of riparian forest of the Piauitinga River, in the municipality of Lagarto (SE).

Figura 1. Modelagem digital de terrenos $(\mathrm{mm})$ caracterizando diferenças de cota entre a porção superior, base e média do terreno em relação ao curso d'água, nas áreas experimentais de mata ciliar do Rio Piauitinga, no município de Lagarto (SE).

The rainfall regime during the period of emergence of seedlings indicated high water volume, reaching a total value of $266.75 \mathrm{~mm}$ in July 2014, which was characterized as the rainiest month of the analyzed period. This month, it was evidenced an event on the 16th, when there was the highest recorded precipitation $(135.5 \mathrm{~mm})$. In the following months, it was observed a significant decrease of rainfall: $75.5 \mathrm{~mm}$ in August, with a peak of $22.25 \mathrm{~mm}$ in one day; and $51.5 \mathrm{~mm}$ in September, with the daily maximum of $15.25 \mathrm{~mm}$.

Soil moisture showed alternation throughout the time, but it tended to a reduction of the standard. All blocks presented the highest values of moisture in places closer to the river's margin, primarily the blocks 1 and 2. In blocks 3 and 4, there was a greater moisture even at the end of the studied series. In blocks 1 and 2, it was observed similar values to those of block 3 on the terrain basis, at 90 days (Figure 2).

With regard to the soil temperature to the depth of $5 \mathrm{~cm}$, it was verified that there was a significant rise in the values in all the blocks analyzed throughout the 90 initial days after seeding. To evaluate each block, it was observed that the block 3 was the one with the lowest temperature values, peaking at $21.8^{\circ} \mathrm{C}$ at the base of the terrain. In blocks 1 and 2, the lowest recorded temperatures were $22.8{ }^{\circ} \mathrm{C}$ at the base and $22.7{ }^{\circ} \mathrm{C}$ at the top, respectively. With regard to higher temperatures, block 1 presented the highest values on almost the entire series. At the end of the studied series, it was observed that the blocks 1 and 4 showed values higher than the other blocks, and block 3 had the lowest values for all sampling points (Figure 3). 

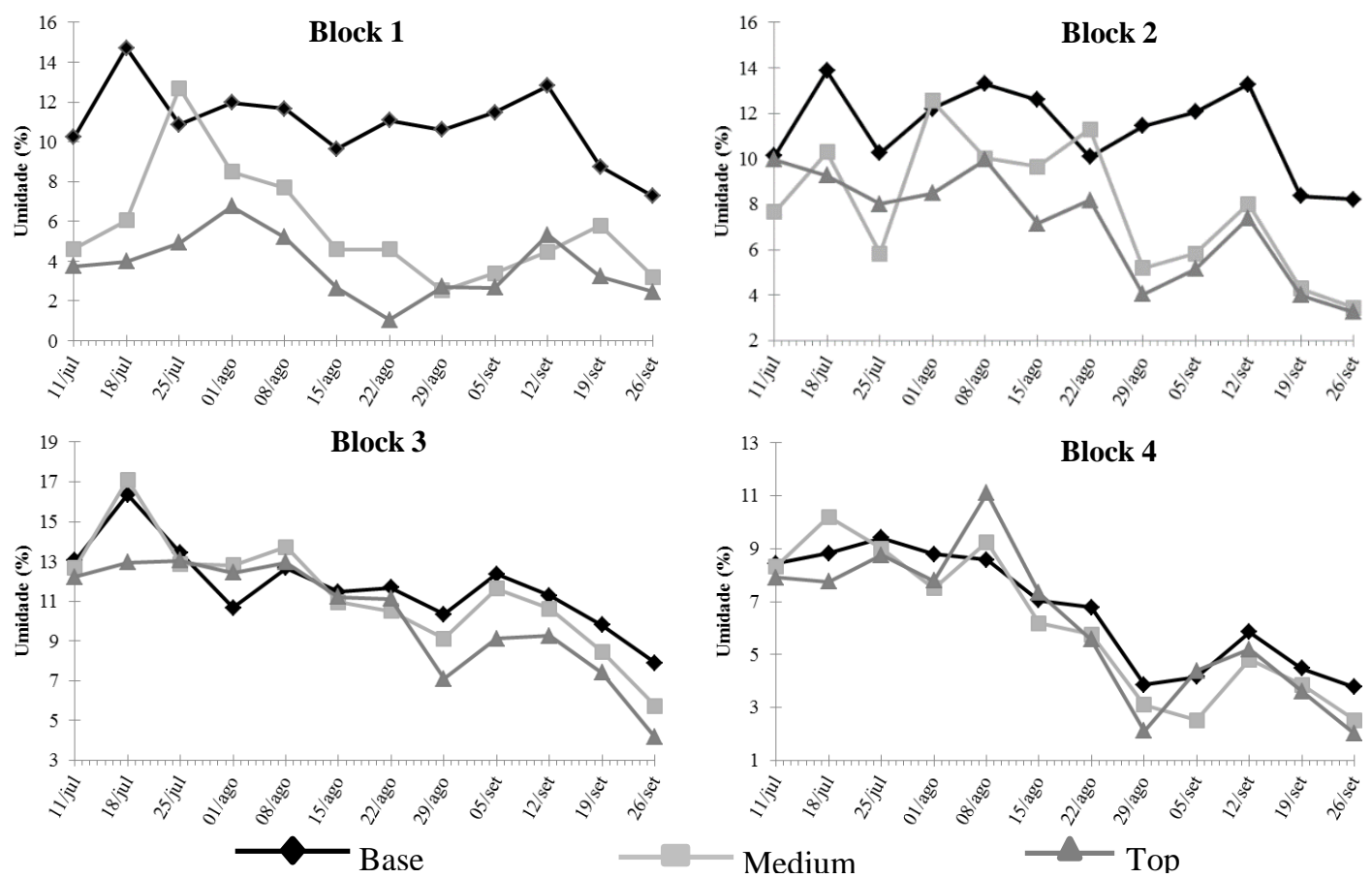

Figure 2. Moisture data (\%) at soil depth of $10 \mathrm{~cm}$ for each block studied, in a riparian area of the Piauitinga River, in the municipality of Lagarto (state of Sergipe, Brazil), during a period of 90 days after sowing in the field.

Figura 2. Dados de umidade (\%) na profundidade do solo de $10 \mathrm{~cm}$ para cada bloco estudado, em área ripária do rio Piauitinga, no município de Lagarto (Sergipe, Brasil), durante um período de 90 dias após a semeadura no campo.
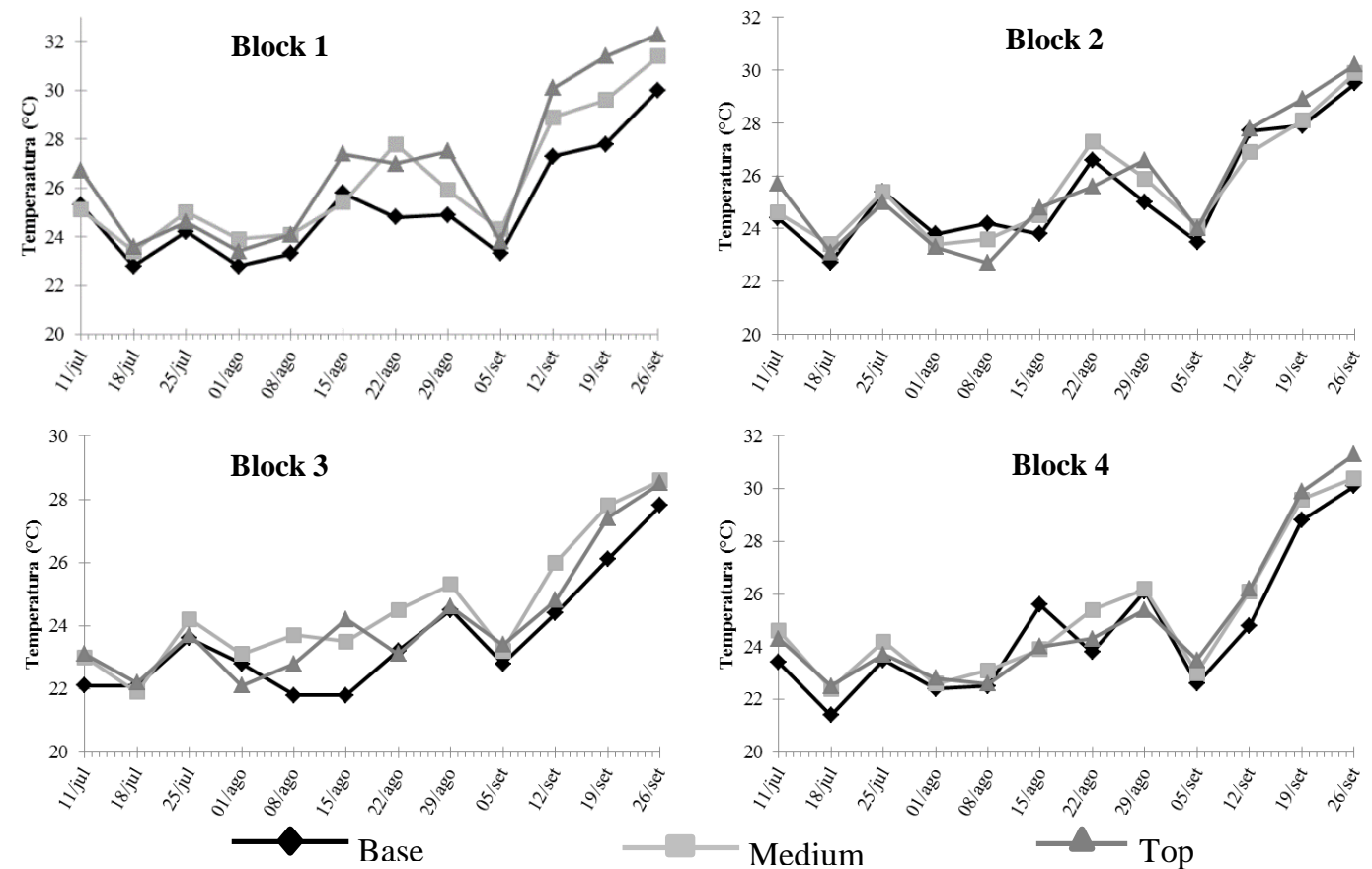

FLORESTA, Curitiba, PR, v. 49, n. 1, p. 057-068, jan/mar. 2019 
Figure 3. Temperature data (\%) at soil depth of $5 \mathrm{~cm}$ for each block studied, in a riparian area of the Piauitinga River, in the municipality of Lagarto (state of Sergipe, Brazil), during a period of 90 days after sowing in the field.

Figura 3. Dados de temperatura (\%) na profundidade de $5 \mathrm{~cm}$ para cada bloco estudado, em área ripária do rio Piauitinga, no município de Lagarto (Sergipe, Brasil), durante um período de 90 dias após a semeadura no campo.

\section{Emergence of seedlings}

Analyzing emergence characteristics, it was observed that there was interaction between species, types of treatment and evaluation $(p>0.05)$ for the percentage of seedling emergence in the field (table 1).

Table 1. Analysis of variance of the emergence for species, treatments and time analyzed.

Tabela 1. Análise de variância da emergência de espécies, tratamentos e análise de tempo.

\begin{tabular}{lccccc}
\hline \multicolumn{1}{c}{ FV } & GL & SQ & QM & Fc & Pr>Fc \\
\hline Block & 3 & 183,1477 & 61,04925 & 2,389 & 0,071 \\
Treatment & 1 & 15,48368 & 15,48368 & 0,606 & 0,438 \\
Species & 3 & 1224,424 & 408,1414 & 15,974 & $0,000^{* *}$ \\
Time & 5 & 22397.94 & 4479,588 & 175.321 & $0,000^{* *}$ \\
Treatment*Species & 3 & 812.6915 & 270,8972 & 10,602 & $0,000^{* *}$ \\
Treatment*Time & 5 & 328,5454 & 65.70907 & 2,572 & $0.029^{*}$ \\
Species*Time & 15 & 5345.792 & 356.3862 & 13,948 & $0,000^{* *}$ \\
Treatment*Species*Time & 15 & 4679,268 & 311.9512 & 12,209 & $0,000^{* *}$ \\
\hline Total & 191 & 38589.96 & & & \\
\hline \multicolumn{7}{c}{$\mathrm{CV}(\%)$} & 59.94 & & & \\
$*$ & &
\end{tabular}

Comparing the emergence responses of species within each studied period, it was found that there were only significant differences in the first 15 days after sowing, both among the species in each treatment as between treatments in each species (Table 2). In seeds treatment with dormancy (CD), Enterolobium contortisiliquum differentiated statistically from the other with $69.75 \%$ of emergence, followed by Cassia grandis, which also presented different average from all the others ( 53.25\%). Guazuma ulmifolia (1,0\%) e Libidibia ferrea var.leiostachya $(0,0 \%)$ were found to be statistically similar. In seeds treatment without dormancy (SD), Cassia grandis statistically differed from other species $(60.25 \%)$, which were similar statistically.

By comparison of the treatments, only Cassia grandis showed no statistical difference between their averages. Enterolobium contortisiliquum was statistically different due to the higher seed emergence with dormancy $(69.75 \%)$ in relation to seed without dormancy (17.5\%), while Guazuma ulmifolia and Libidibia ferrea var.leiostachya had higher averages in seeds with dormancy-breaking treatment (22.5\% and $25.75 \%$, respectively).

Table 2. Seedlings emergence (\%) of Cassia grandis (Cg)Enterolobium contortisiliquum (Ec)Guazuma ulmifolia $(\mathrm{Gu})$ and Libidibia ferrea var.leiostachya. (Lf), from seeds with (CD) and without (SD) dormancy in each evaluation period $(15,30,45,60,75$ and 90 days after direct sowing), by the Tukey test at $5 \%$ significance, in riparian forest of the Piauitinga River, in the municipality of Lagarto (state of Sergipe, Brazil).

Tabela 2. Emergência de mudas (\%) de Cassia grandis (Cg), Enterolóbio contortisiliquum (Ec), Guazuma ulmifolia $(\mathrm{Gu})$ e Libidibia ferrea var. leiostachya. (Lf), de sementes com dormência (CD) e sem (SD) em cada período de avaliação $(15,30,45,60,75$ e 90 dias após a semeadura direta), pelo teste de Tukey a 5\% de significância, em mata ciliar do rio Piauitinga, no município de Lagarto (estado de Sergipe, Brasil). 


\begin{tabular}{|c|c|c|c|c|c|c|c|c|}
\hline \multirow[b]{2}{*}{ Treatment } & \multicolumn{8}{|c|}{ Species } \\
\hline & & $\mathrm{Cg}$ & & Ec & & Gu & & Lf \\
\hline \multicolumn{9}{|c|}{15 Days after sowing } \\
\hline CD & $46.91^{2}$ & $(53.25)^{1} \mathrm{bA}$ & 56,75 & $(69.75) \mathrm{aA}$ & 6,93 & $(1.50) \mathrm{cB}$ & 4,97 & $(1.50) \mathrm{cB}$ \\
\hline SD & 51,06 & $(60.25) \mathrm{aA}$ & 23,53 & $(17.50) \mathrm{cB}$ & 27,51 & (22.50) cA & 37,10 & (37.12) bA \\
\hline \multicolumn{9}{|c|}{30 Days after sowing } \\
\hline CD & 4,67 & $(1.50) \mathrm{aA}$ & 4,90 & $(1.00) \mathrm{aA}$ & 1,43 & $(0.25) \mathrm{aA}$ & 7,62 & $(2.63) \mathrm{aA}$ \\
\hline SD & 5,72 & $(2.00) \mathrm{aA}$ & 3,47 & $(0.75) \mathrm{aA}$ & 4,07 & $(1.00) \mathrm{aA}$ & 8,45 & $(2.88) \mathrm{aA}$ \\
\hline \multicolumn{9}{|c|}{45 Days after sowing } \\
\hline CD & 1,43 & $(0.25) \mathrm{aA}$ & 0,00 & $(0.00) \mathrm{aA}$ & 1,43 & $(0.25) \mathrm{aA}$ & 4,13 & (1.13) aA \\
\hline SD & 0,00 & $(0.00) \mathrm{aA}$ & 0,00 & $(0.00) \mathrm{aA}$ & 0,00 & $(0.00) \mathrm{aA}$ & 0,00 & $(0.00) \mathrm{aA}$ \\
\hline \multicolumn{9}{|c|}{60 Days after sowing } \\
\hline CD & 3,93 & $(1.00) \mathrm{bB}$ & 9,90 & (3.25) abA & 1,43 & $(0.25) \mathrm{bA}$ & 14,97 & $(8.50) \mathrm{aA}$ \\
\hline SD & 11,47 & $(6.00) \mathrm{aA}$ & 4,07 & $(1.00) \mathrm{aA}$ & 8,15 & $(2.75) \mathrm{aA}$ & 8,61 & $(3.00) \mathrm{aA}$ \\
\hline \multicolumn{9}{|c|}{75 Days after sowing } \\
\hline CD & 6,35 & $(1.75) \mathrm{bA}$ & 0,00 & $(0.00) \mathrm{bA}$ & 0,00 & $(0.00) \mathrm{bA}$ & 17,81 & (11.63) aA \\
\hline SD & 3,93 & $(1.00) \mathrm{aA}$ & 3,47 & $(0.75) \mathrm{aA}$ & 1,43 & $(0.25) \mathrm{aA}$ & 7,18 & $(1.75) \mathrm{aB}$ \\
\hline \multicolumn{9}{|c|}{90 Days after sowing } \\
\hline CD & 0,00 & $(0.00) \mathrm{aA}$ & 0,00 & $(0.00) \mathrm{aA}$ & 0,00 & $(0.00) \mathrm{aA}$ & 0,00 & $(0.00) \mathrm{aA}$ \\
\hline SD & 0,00 & $(0.00) \mathrm{aA}$ & 0,00 & $(0.00) \mathrm{aA}$ & 0,00 & $(0.00) \mathrm{aA}$ & 0,00 & $(0.00) \mathrm{aA}$ \\
\hline
\end{tabular}

${ }^{1}$ Data transformed in $\arcsin \sqrt{x / 100} ;{ }^{2}$ Data not transformed. Averages followed by the same capital letter in the column and lowercase in the row do not differ from each other by the Tukey test at $5 \%$ probability.

Analyzing the temporal behavior of the emergence of the studied species, it appears that they showed an percentage emergence pattern over the 90 days after sowing in the field. In General, note that there are significant emergence in early stage soon after sowing and at the end of the analyzed period for both treatments (Figure 4). The biggest emergence percentage are checked in the first 15 days, with decrease until 30 days, and little or no percentage at 45 days.

The species Cassia grandis stood out, getting the biggest emergences until 15 days after sowing in both treatments $(46.91 \%$ for seeds with dormancy and $51.06 \%$ for those without dormancy). Also, Enterolobium contortisiliquum presented 56,75\% for seeds with dormancy and Guazuma ulmifolia, 27,51\% for seeds without dormancy. In the period from 60 to 75 days, even if a little, emergence increased. At 90 days, there was no more emergence in all species in both treatments. The exception was observed in Libidibia ferrea var. leiostachya for dormant seeds. The species presented low emergence until 15 days and, in general, low emergence until 60 days, period which can be observed an emergence peak (14.97\%) that later came back to decrease. 

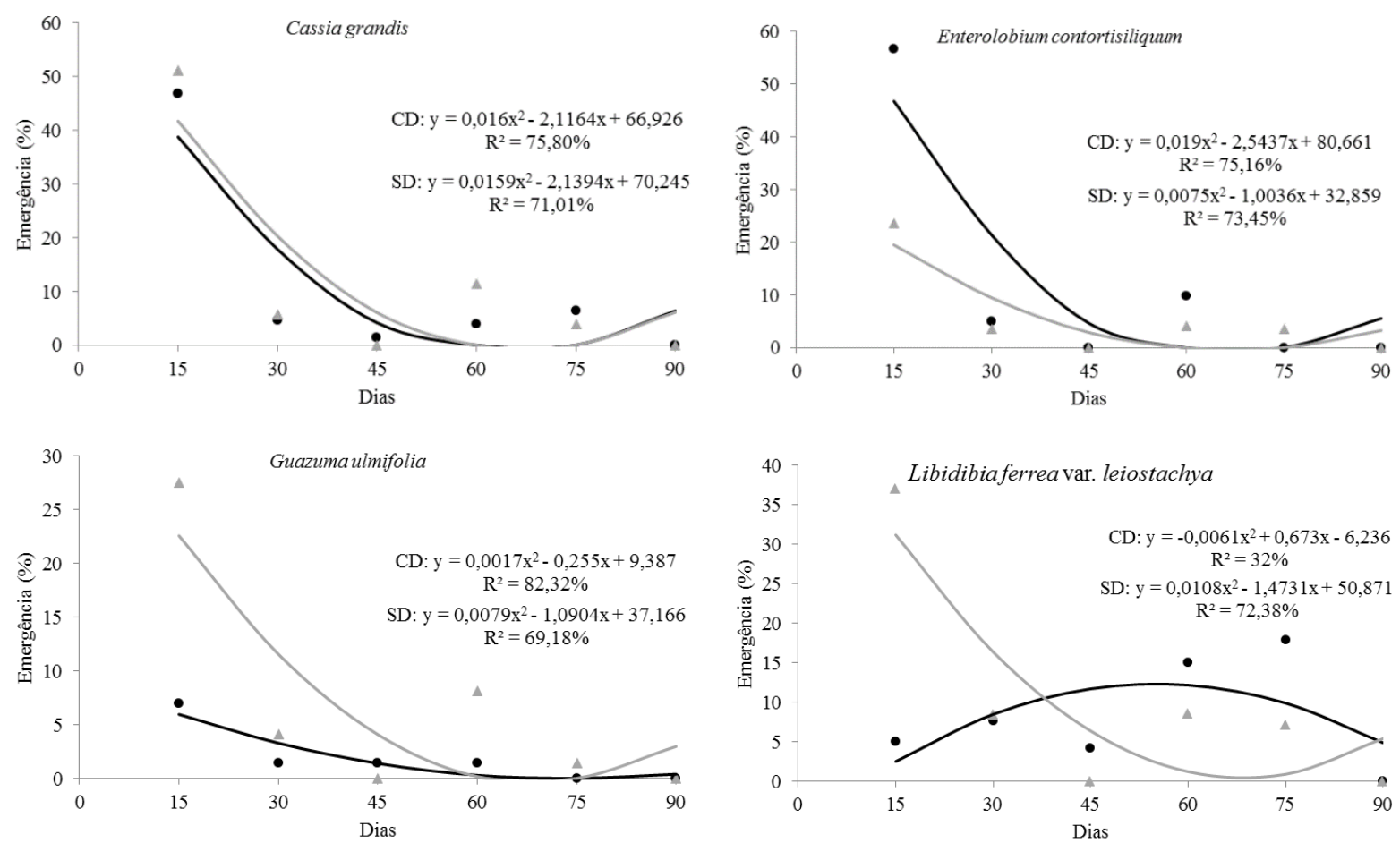

- With dormancy (CD)

Without dormancy

Figure 4. Emergence of seedlings (\%) of Cassia grandis, Enterolobium contortisiliquum, Guazuma ulmifolia and Libidibia ferrea var.leiostachya, from seeds with (CD) and without (SD) dormancy according to time (15, $30,45,60,75$ and 90 days after sowing) in riparian area of the Piauitinga River, in the municipality of Lagarto (state of Sergipe, Brazil).

Figure 4. Emergência de plântulas (\%) de Cassia grandis, Enterolobium contortisiliquum, Guazuma ulmifolia e Libidibia ferrea var.leiostachya, de sementes com (CD) e sem (SD) dormência de acordo com o tempo $(15,30,45,60,75$ e 90 dias após semeadura) em área ripária do rio Piauitinga, no município de Lagarto (estado de Sergipe, Brasil).

It is observed that, in relation to the observed emergence curve, the seeds with treatment to overcome dormancy had a greater and more anticipated emergence in comparison with dormant seeds, except for the species Enterolobium contortisiliquum. However, for both treatments, there is a time pattern of seedling emergence in all species (except for dormant seeds of the species Libidibia ferrea var. leiostachya).

\section{DISCUSSION}

Along the topographic profile of the terrain blocks, it was found that the temperatures at the base showed lower values, once they had higher values of soil moisture, and temperature increased gradually in relation to the elevation of the terrain. That is conditioned, mainly, by the precipitations, which promote exchanges of heat between soil and water, resulting in mild temperatures, which influence soil organisms. The precipitation with high peak after July 16 also raised soil moisture degree of all blocks and, consequently, reduced their temperatures, time which the lowest values were observed throughout the analyzed series. Rainfall interference on soil temperature is clearly verified not only by the temporal trend, but also by the peaks and reductions of daily accumulations. Such situation is noted in the accumulated rainfall.

This condition, in which there are different responses for different species as a result of temperature, can also justify the emergence responses of seedlings in the analized blocks, as this field variable can be directly affected 
in case of emergence of seedlings, considering that some species germinate best at constant temperature, while others require alternating temperatures to germinate properly (ADAM et al., 2013). In blocks 1 and 2, higher temperature values were observed compared to blocks 3 and 4, which resulted in a higher percentage of emerged seedlings. For example, Enterolobium contortisiluquum with seeds without treatment to overcome dormancy presented equal values in the blocks 1 e 2 (73\%), briefly in the first period of evaluation.

This influence could be verified by laboratory tests performed by Ribeiro et al.. (2012), which found that different temperature values resulted in distinct variations in germination percentage. Enterolobium contortisiluquum, for example, obtained minimum value of $42 \%$ at $20{ }^{\circ} \mathrm{C}$ and $92 \%$ at $35^{\circ} \mathrm{C}$, and Guazuma ulmifolia varied from $57 \%$ to $65 \%$ for the same temperatures respectively. It can be verified, then, that there is not an optimum and uniform temperature for all the species, since they present a variable behavior in different temperatures. Even so, a temperature that allows maximum germination in the shortest time is craved, considering the best temperature for germination (GH et al.., 2010).

In moist soils, the temperature is one of the factors that determines both the percentage and speed of germination, being the value dependent on a variable amplitude for each species. That acts in seeds without dormancy and dormant ones, since it can be a factor to overcome the germination impediment (RIBEIRO et al.., 2012), situation found in the environment here studied, in which moisture values were significant.

Thus, as a result of the rainfall, the moisture factor had great influence on the percentage of seedling emergence of studied species. According to Adams et al.. (2012), the seed in higher moisture soil absorbs more water, which results in the increase of their volume, breaking the integument and facilitating the germinative process. According to Ghani et al.. (2013), to associate the emergence of seedlings with water regime allows to understand to which environments species are adapted and their ecological interactions according to their requirements and tolerances. The authors cited, while studing seeds germination of Apeiba tibourbou, noted that the seeds demonstrated no character for adaptive species, resulting in low capacity of establishment in field also they reduced survival rate due to water stress.

Although the importance of the water for germination, in great volumes, can be harmful to this process. This was evidenced in the species used in this study, since there was a flood in the pits after large rainfall accumulations, and the seeds with and without pré-germinative treatment had reduced the amount of emergence. Initially, there was an increasing trend in the values however high rainfall caused soil drenching, causing seed deterioration, which may have affected, mainly, the species Guazuma ulmifolia, which presented low emergence values. However, the seeds without dormancy presented higher values, especially in block 4, where peaked at 33\% of emergence in the very first week. This was the highest value reached by the species and, at the end of the studied period, there was an increase of $11 \%$, responding well over the 90 days. These responses may be associated with good retention of water at the seed site, since the seeds were not impeded to initiate the emergence process.

This was not seen in other blocks due to their position along the profile of the terrain. It was under high moisture conditions on the basis of the block. There was thus a great accumulation of water and loss of potential of seed germination. However, Lacerda and Figueiredo (2009) verified a much higher value than the one found in the present study, reaching at $71.3 \%$ of the species emergence also in forest restoration activities in riparian forest, in the Mearim River, in the municipality of Barra do Corda (state of Maranhão). This species had an emergence linked to the help overcoming dormancy, reaching an average of $26.50 \%$. Even so, the value is lower than the results obtained by Malavasi et al.. (2010), who observed a percentage of $31.11 \%$ to a maximum of $65.44 \%$ depending on the weather station, and Meneghello and Mattei (2004), who observed 37\% of emergence.

The species Enterolobium contortisiluquum with untreated seeds for overcoming dormancy stood out with the highest rates of emergence, showing a value far superior to that found for Lacerda and Figueiredo (2009), who observed only 35\%. Costa et al. (2011) observed difference among averages when comparing the species Enterolobium contortisiliquum and Cassia grandis with (55\% and 73\%, respectively) and without dormancy (2\% and 19\%, respectively), when employed mechanical scarification in controlled environment. Bezerra et al. (2012), comparing Cassia grandis, verify a difference of $6 \%$ of germination for dormant seeds and until $65 \%$ for those without dormancy, in the laboratory.

On the other hand, the seeds of Libidibia ferrea var.leiostachya without treatment for overcoming dormancy presented a singular behavior of emergence, differentiating itself from other species in the two treatments used. It must be connected to the difficulty of overcoming dormancyto accross time, not showing such sensitivity from seed to moisture and temperature conditions of the area, as seen with Enterolobium contortisiluquum.

FLORESTA, Curitiba, PR, v. 49, n. 1, p. 057-068, jan/mar. 2019

Jesus. J.B. et.al.

Electronic ISSN 1982-4688

DOI: $10.5380 /$ rf.v49i1.56202 


\section{CONCLUSION}

- The emergence of seedlings is affected by the presented factors, as well as by environmental conditions (precipitation, soil temperature and the topography of the terrain), which influenced the behaviour and percentage of seedlings emergence (mainly moisture, since it was about a riparian area). Therefore, there must be used species adapted to the influence of these natural variables to ensure the success of forest recovery activity.

- The species studied showed that there is a pattern regarding their emergence response over time, with a significant part of seedlings emerging in the first weeks after sowing, period which requires greater care in monitoring of riparian area reforestation projects.

\section{ACKNOWLEDGMENTS}

The Coordination for the Improvement of Higher Level Personel (CAPES) for financial support that helped in the fieldwork, as well as the CNPq/COPES/UFS and the project Adote um Manancial for the research completion support.

\section{REFERENCES}

ALVES, M. M.; ALVES, E. U.; BRUNO, R. L. A.; SILVA, K. R. G. da; SANTOS-MOURA, S. S.; BARROZO, L. M. Potencial fisiológico de sementes de Clitoria fairchildiana R.A. Howard.- Fabaceae submetidas a diferentes regimes de luz e temperatura. Revista Ciência Rural, Santa Maria, v. 42, n. 12, p. 2199-2205, 2012.

ALVES, M. M.; ALVES, E. U.; BRUNO, R. L. A.; SILVA, K. R. G. da; BARROZO, L. M.; SANTOS-MOURA, S. S.; CARDOSO, E. A. Germinação e vigor de sementes de Clitoria fairchildiana Howard (Fabaceae) em função da coloração do tegumento e temperaturas. Bioscience Journal, Uberlândia, v.29, n. 1, p. 216-223, 2013.

BEZERRA, F. T. C.; ANDRADE, L. A.; BEZERRA, M. A. F.; PEREIRA, W. E.; FABRICANTE, J. R.; OLIEIRA, L. S. B.; FEITOSA, R. C. Biometria de frutos e sementes e tratamentos pré-germinativos em Cassia grandis L. f. (Fabaceae). Semina: Ciências Agrárias, Londrina, v. 33, suplemento 1, p. 2863-2876, 2012.

BRASIL. Regras para análise de sementes. Brasília: Ministério da Agricultura, Pecuária e Abastecimento, 1 ed. 2009, 399 p.

COSTA, M. do P.; NAPPO, M. E.; CAÇADOR, F. R. D.; BARROS, H. H. D. de. Avaliação do processo de reabilitação de um trecho de floresta ciliar na Bacia do Rio Itapemirim-ES. Revista Árvore, Viçosa, v. 34, n. 5, p. 835-851, 2010.

COSTA, T. G.; DIAS, A. H. S.; ELIAS, T. F.; BREIER, T. B.; ABREU, H. S. Lignina e a dormência em sementes de três espécies de leguminosas florestais da Mata Atlântica. Revista Floresta e Ambiente, Rio de Janeiro, v. 18, n. 2, p. 204-209, 2011.

EMPRESA BRASILEIRA DE PESQUISA AGROPECUÁRIA (EMBRAPA). Manual de Métodos de Análise de Solo. Rio de Janeiro: Centro Nacional de Pesquisa de Solos, 2 ed. 1997, 212 p.

FERREIRA, D. F. Sisvar: a computer statistical analysis system. Ciência e Agrotecnologia, v. 35, n.6, p. 10391042, 2011.

FERREIRA, P. I.; GOMES, J. P.; BATISTA, F.; BERNARDI, A. P.; COSTA, N. C. F.; BORTOLUZZI, R. L. C.; MANTOVANI, A. Espécies Potenciais para Recuperação de Áreas de Preservação Permanente no Planalto Catarinense. Revista Floresta e Ambiente, Rio de Janeiro, v. 20, n. 2, p. 173-182, 2013.

GUEDES, R. S., ALVES, E. U., GONÇALVES, E. P., BRAGA JÚNIOR, J. M., VIANA, J. S., \& COLARES, P. N. Q. Substratos e temperaturas para testes de germinação e vigor de sementes de Amburana cearensis (Allemão) A.C. Smith. Revista Árvore, Viçosa, v. 34, n. 1, p. 57-64, 2010. 
GUEDES, R. S.; ALVES, E. U.; VIANA, J. S.; GONÇALVES, E. P.; LIMA, C. R.; SANTOS, S. R. N. Germinação e vigor de sementes de Apeiba tibourbou submetidas ao estresse hídrico e diferentes temperaturas. Ciência Florestal, Santa Maria, v. 23, n. 1, p. 45-53, 2013.

LACERDA, D. M. A.; FIGUEIREDO, P. S. Restauração de matas ciliares do rio Mearim no município de Barra do Corda-MA: seleção de espécies e comparação de metodologias de reflorestamento. Acta Amazonica, Manaus, v. 39, n. 2, p. 295-304, 2009.

LIMA, Y. B. C.; DURIGAN, G.; SOUZA, F. M. Germinação de 15 espécies vegetais do cerrado sob diferentes condições de luz. Bioscience Journal, Uberlândia, v. 30, n. 6, p. 1864-1872, 2014.

MALAVASI, U. C.; KLEIN, J.; MALAVASI, M. M. Efeito de um protetor físico na semeadura direta de duas espécies florestais em área de domínio ciliar. Revista Árvore, Viçosa, v. 34, n. 5, p. 781-787, 2010.

MENEGHELLO, G. E.; MATTEI, V. L. Semeadura direta de timbaúva (Enterolobium contortisiliquum), canafístula (Peltophorum dubium) e cedro (Cedrela fissilis) em campos abandonados. Ciência Florestal, Santa Maria, v. 14, n. 2, p. 21-27, 2004.

OliVEIRA-FILHO, A.T., VILELA, E. A., CARVALHO, D. A.; GAVILANES, M. L. Estudos florísticos e fitossociológicos em remanescentes de matas ciliares do Alto e Médio Rio Grande. Belo Horizonte: CEMIG, 1995. $27 \mathrm{p}$.

PEREIRA, S. R.; LAURA, V. A.; SOUZA, A. L. T. de. Superação de dormência de sementes como estratégia para restauração florestal de pastagem tropical. Pesquisa Agropecuária Brasileira, Brasília, v. 48, n. 2, p. 148-156, 2013.

PEREIRA, Z. V.; RIBEIRO, J. F.; OGATA, R.; PADOVAN, M. P. Semeadura Direta Mecanizada na Recuperação de Reserva Legal com Diversificação de Espécies do Bioma Cerrado do Distrito Federal. Cadernos de Agroecologia, v. 9, n. 4, p. 1-11, 2014.

RIBEIRO, E. S.; OLIVEIRA, D. P.; SOUZA, R. S.; PASA, M. C.; SOUZA, R. A. T. C. Efeito da temperatura na germinação de sementes de Enterolobium contortisiliqunn (Vell,) Morong - (Mimosoidae) e Guazuma ulmifolia (Sterculiaceae). Biodiversidade, Rondonópolis, v. 11, n. 1, p. 23-30, 2012.

ROCHA, J. H. T.; SANTOS, A. J. M.; DIOGO, F. A.; BACKES, C.; MELO, A. G. C. de.; BORELLI, K.; GODINHO, T. de O. Reflorestamento e recuperação de atributos químicos e físicos do solo. Revista Floresta e Ambiente, Rio de Janeiro, v. 22, n. 3, p. 299-306, 2015.

SERGIPE (Estado). Secretaria de Estado do Planejamento, da Ciência e da Tecnologia. Atlas digital sobre recursos hídricos Sergipe, SEPLANTEC/SRH, 2011, (CD-ROM).

SOUZA, I. F. de; SILVA, V. de P. R. da; SABINO, F. G.; AGUIAR NETTO, A. de O.; SILVA, B. K. N.; AZEVEDO, P. V. de. Evapotranspiração de referência nos perímetros irrigados do Estado de Sergipe. Revista Brasileira de Engenharia Agrícola e Ambiental, v. 14, n. 6, p. 633-644, 2010.

FLORESTA, Curitiba, PR, v. 49, n. 1, p. 057-068, jan/mar. 2019

Jesus. J.B. et.al.

Electronic ISSN 1982-4688

DOI: $10.5380 /$ rf.v49i1.56202 
FLORESTA, Curitiba, PR, v. 49, n. 1, p. 057-068, jan/mar. 2019 Jesus. J.B. et.al.

Electronic ISSN 1982-4688 DOI: $10.5380 /$ rf.v49i1.56202 